Pale pink needles of composition $\left[\mathrm{Co}\left(\mathrm{H}_{2} \mathrm{O}\right)_{4}(\mathrm{Ade})_{2}\right](\mathrm{AdeH})_{2}$ $\left(\mathrm{SO}_{4}\right)_{2} .6 \mathrm{H}_{2} \mathrm{O}$ (where AdeH represents the protonated adeninium cation $\mathrm{C}_{5} \mathrm{H}_{6} \mathrm{~N}_{5}{ }^{+}$) were obtained from aqueous solutions of adenine and cobalt (II) sulphate in $2: 1 \mathrm{~mol}$ ratio. (Analytical results: Found, $\mathrm{C}, 24.4 ; \mathrm{H}, 3.8 ; \mathrm{N}, 28.7 ; \mathrm{S}, 6.6$; calculated, C, 24.65; H, 4.35; N, 28.8; S, 6.6\%.) The crystals are monoclinic, with unit cell dimensions $a=13.971$, $b=7.190, c=19.900 \AA, \beta=101.82^{\circ}, U=1956.6 \AA^{3}$, space group $P 2_{1} / n$ and $Z=2$. The structure has been determined on the basis of 2,275 independent reflexions measured on a Siemens four-circle diffractometer using $\mathrm{Cu}-\mathrm{K}_{\alpha}$ radiation. Leastsquares refinement has now reached $R=0.065$.

The structure contains the crystallographically centrosymmetric $\left[\mathrm{Co}\left(\mathrm{H}_{2} \mathrm{O}\right)_{4}(\mathrm{Ade})_{2}\right]^{2}+$ ion, $\mathrm{AdeH}$ and sulphate ions, and molecules of water of solvation, all connected by an intricate network of hydrogen bonds. In the complex cation (Fig. 1) the cobalt atom has an octahedral coordination and the coordinated adenine is monodentate, bonding via $\mathrm{N}(9)$, as in $\left[\mathrm{Cu}(\mathrm{AdeH})_{2} \mathrm{Br}_{2}\right] \mathrm{Br}_{2}$ (refs. 2, 3) while in $\mathrm{Zn}(\mathrm{AdeH}) \mathrm{Cl}_{3}$ (ref. 4) it bonds via $N(7)$. In the other three metal-adenine complexes whose structures have been determined hitherto, the inner complex $\left[\mathrm{Cu}\left(\mathrm{C}_{5} \mathrm{H}_{4} \mathrm{~N}_{5}\right)_{2} \mathrm{H}_{2} \mathrm{O}\right]_{2} \cdot 6 \mathrm{H}_{2} \mathrm{O}$ (ref. 5), $\left[\mathrm{Cu}(\mathrm{Ade})_{2} \mathrm{Cl}\right]_{2}$ $\mathrm{Cl}_{2} \cdot 6 \mathrm{H}_{2} \mathrm{O}$ (refs. 6, 7), and $\mathrm{Cu}_{3} \mathrm{Cl}_{8}(\mathrm{AdeH})_{2} \cdot 4 \mathrm{H}_{2} \mathrm{O}$ (refs. 8, 9), adenine acts as a bridging ligand bonding via $\mathrm{N}(3)$ and $\mathrm{N}(9)$.

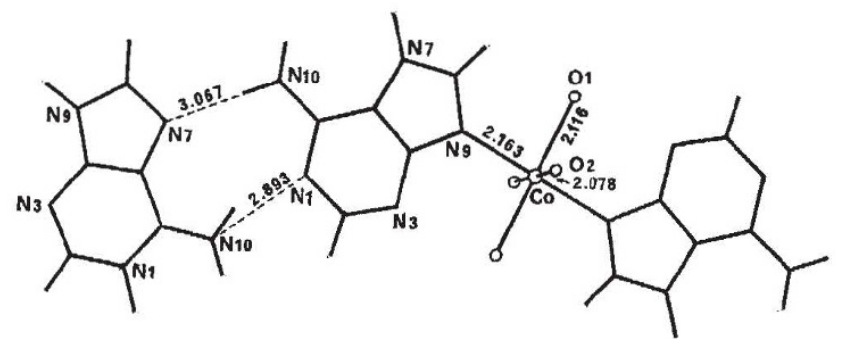

Fig. 1 A fragment of the structure showing the centrosymmetric $\left[\mathrm{Co}\left(\mathrm{H}_{2} \mathrm{O}\right)_{4}(\text { Ade })_{2}\right]^{2+}$ ion and a hydrogen-bonded AdeH group. Standard deviations are: $\mathrm{Co}-\mathrm{O}, 0.005 ; \mathrm{Co}-\mathrm{N}, 0.005$; and N... N, $0.009 \AA$.

We have been able to locate unequivocally the positions of the hydrogen atoms for both the Ade and AdeH moieties, and have indicated them in Fig. 1. The hydrogen bond network found in this structure contains the following types of bond: $\mathrm{O}-\mathrm{H} \ldots \mathrm{O}, \mathrm{N}-\mathrm{H} \ldots \mathrm{O}, \mathrm{O}-\mathrm{H} \ldots \mathrm{N}, \mathrm{N}-\mathrm{H} \ldots \mathrm{N}$, and possibly C-H . . . O. The full structural details will be published elsewhere.

Another feature of this structure which is of some biological interest is the presence of hydrogen-bonded pairs Ade-AdeH oriented as shown in Fig. 1. Of the two $\mathrm{N}-\mathrm{H}$. . . N hydrogen bonds joining the pair $N(10)-H ~ \ldots . N(1)$ is the shorter one. A similar connexion of Ade units is found in 9-methyladenine ${ }^{10}$ and in deoxyadenosine monohydrate ${ }^{11}$. These, however, form an infinite zigzag chain whereas in this structure the interaction is limited to a discrete pair because of protonation at the crucial $\mathrm{N}(1)$ site in AdeH.

Although caution should be exercised in making an extrapolation to complex biological systems, it is conceivable that if under certain conditions an individual adenine base in a nucleic acid becomes protonated, then this may help to stabilize an abnormal adenine-adenine pairing. The rare, even transient, formation of such a linkage followed by normal replication provides one simple mechanism for a mutation, where in this case Thy is substituted for Ade in the DNA sequence. This abnormal pairing may also occur in the transcription stages involving RNA, the end product in each case being a single erroneous amino-acid in the peptide sequence or an aberration in the chain termination process.
We thank the Royal Society for a European Science Exchange Programme fellowship (to P. de Meester).
P. DE MEESTER
D. M. L. Goodgame
D. J. RichmaN
A. C. SKapski

Chemical Crystallography and

Inorganic Chemistry Laboratories,

Imperial College,

London SW7 2AY

Received November 15, 1972; revised January 11, 1973.

${ }^{1}$ Eichhorn, G. L., Berger, N., Butzow, J., Clark, P., Rifkind, J., Shin, Y., and Tarien, E., Advan. Chem. Ser., No. 100, 135 (1971).

2 de Meester, P., Goodgame, D. M. L., Price, K. A., and Skapski, A. C., Biochem. Biophys. Res. Commun., 44, 510 (1971).

3 de Meester, P., and Skapski, A. C., J. Chem. Soc. (Dalton), 424 (1973).

${ }^{4}$ Srinivasan, L., and Taylor, M. R., Chem. Comm., 1668 (1970).

5 Sletten, E., Acta Cryst., B, 25, 1480 (1969).

6 de Meester, P., Goodgame, D. M. L., Price, K. A., and Skapski, A. C., Nature, 229, 191 (1971).

7 de Meester, P., and Skapski, A. C., J. Chem. Soc. (A), 2167 (1971).

8 de Meester, P., Goodgame, D. M. L., Price, K. A., and Skapski, A. C., Chem. Comm., 1573 (1970).

9 de Meester, P., and Skapski, A. C., J. Chem. Soc. (Dalton), 2400 (1972).

${ }^{10}$ Stewart, R. F., and Jensen, L. H., J. Chem. Phys., 40, 2071 (1964).

11 Watson, D. G., Sutor, D. J., and Tollin, P., Acta Cryst., 19, 111 (1965).

\section{On Boiling an Egg}

Dwek and Navon ${ }^{1}$ give the temperature of boiling water on the top of Pike's peak as $91^{\circ} \mathrm{C}$; at an altitude of 14,110 foot the atmospheric pressure should correspond to a boiling point of $86^{\circ} \mathrm{C}$. I can, however, confirm their observations from experimental results obtained at 7,300 foot $\left(93^{\circ} \mathrm{C}\right.$ boiling point); these indicate that an egg may be hard-boiled in 12 minutes. My results support these authors' contention that considerably less than $12 \mathrm{~h}$ is required, either at $91^{\circ}$ or $86^{\circ} \mathrm{C}$, to hard-boil an egg.

\section{E. H. Plassman}

\section{Los Alamos Scientific Laboratory,}

University of California,

Los Alamos,

New Mexico 87544

Received February 12, 1973.

${ }^{1}$ Dwek, R. A., and Navon, G., Nature, 240, 491 (1972).

\section{BIOLOGICAL SCIENCES}

\section{Isolation of the Islets of Langerhans for Transplantation}

PANCREATIC transplantation with the aim of treating diabetes mellitus has so far met with little success. Of 23 patients thus treated and reported to the Transplant Registry in $1971^{1}, 15$ died within 3 months and the longest survived one year. One of the major problems has been to overcome pancreatic exocrine digestion, and pancreatic duct ligation ("Banting pancreas") before transplantation has been performed. It was shown by Dragstedt ${ }^{2}$, however, that dogs treated in this way often became diabetic or showed a diabetic glucose tolerance test after several months, probably due to fibrosis and consequent ischaemia of the Islets. Transplantation of the whole 